John Carroll University

Carroll Collected

2018 Faculty Bibliography

Faculty Bibliographies Community Homepage

2018

\title{
Heroines, Heroes and Deity: Three Narratives of the Biblical Heroic Tradition
}

John R. Spencer

John Carroll University, spencer@jcu.edu

Follow this and additional works at: https://collected.jcu.edu/fac_bib_2018

Part of the Religion Commons

\section{Recommended Citation}

Spencer, John R., "Heroines, Heroes and Deity: Three Narratives of the Biblical Heroic Tradition" (2018). 2018 Faculty Bibliography. 50.

https://collected.jcu.edu/fac_bib_2018/50

This Book Review is brought to you for free and open access by the Faculty Bibliographies Community Homepage at Carroll Collected. It has been accepted for inclusion in 2018 Faculty Bibliography by an authorized administrator of Carroll Collected. For more information, please contact connell@jcu.edu. 
nolores g. Kamrada, Heroines, Heroes and Deity: Three Narratives of the Biblical ITeroic Tradition (I.HBOTS 621; London: Bloomsbury T\&T Clark, 2016). Pp. xxviii + 204. $\$ 112$.

This volume is a revised dissertation from the University of Vienna. Three portions of the book (about one-third) appeared previously in other volumes. This book is composed of five parts: "Introduction"; chap. 1, "The Sacrifice of Jephthah's Daughter"; chap. 2 , "Hairy Samson: The Function of the Hair Motif in the Samson Cycle"; chap. 3, "Urim and Thummim Saul and David"; and "Closing Reflections." In addition, the volume includes a bibliography, an index of references (biblical and nonbiblical), and an index of authors.

The introduction briefly discusses the three narratives under consideration: Judg

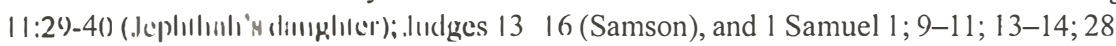

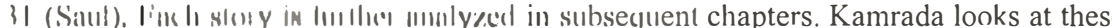
ICxts

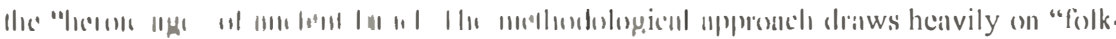

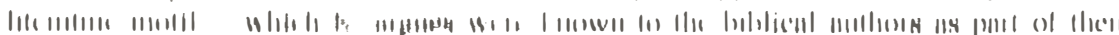


"cultural memory." She acknowledges that the stories have multiple layers of editing anıl are products of a much later time than the periods they depict. Specifically, they ultimately reflect the hand of the Deuteronomistic Historian and his theology, but they are not from the postexilic period. The Deuteronomistic Historian's theology is characterized by llik presence of the divine spirit, extermination of enemies (hêrem), and divination (often Uriıı and Thummim). Furthermore, all of the main characters in these stories reflect heroism exceptional physical abilities, a desire for success, and self-consciousness of their stalus All of this leads to their potential (and real) downfall. Through all of this, K. seeks to show how the stories have changed from "ritual coherence" (legendary stories of cultural meıı ory) to "textual coherence" (the written text).

Chapter 2 deals with the story of Jephthah's daughter. For K. this is a story borroweil from an earlier, "well-known" folk story and later adapted by the Deuteronomistic Hisı।, rian. It is the story of a woman who sacrifices herself for the sake of the community illul thus is a heroine. To support this, $\mathrm{K}$. claims that the daughter knew about her father's vou and thus died willingly to fulfill a "positive" herem, which is accepted by Yhwh. Her clenll, is thus not condemned by the authors since it is "self-sacrifice." In addition, the daughte time away before her death (Judg 11:37-40) is claimed to be the basis of a female "m marital rite of passage" that became a ritual in the community. Jephthah himself is seell : being overly ambitious in war and politics and ends up childless as his punishment.

In the story of Samson, based on the folklore motif of the "wild man," K. tries I" "demonstrate the basic similarity to a presumed "original" (folk) story" (p. 68). To suppon। this she refers to stories about Heracles, Humbaba, and Asherah and to the Hungarian innI Grimm brothers' folktales. Samson is given a miraculous birth, takes on characteristics ॥I a Nazirite, and is linked to Yhwh. When he loses his hair, he also loses his connection will Yhwh, although the link (divine spirit) is restored when his hair regrows. The chapter ('inl with K. seeking to build links between Samson and Jephthah's daughter.

In chap. 3, K. seeks to connect Saul with Samson and Jephthath and then turns all'וl tion to the Urim and Thummim as vehicles of divination used in a "ritual context." fin I it is a "binary" determination-yes or no: an Urim response means a curse; and a Thumı!n! ! response means "without fault." She then argues that the lack of a response from Y/ıw (e.g., 1 Sam 14:37) should be understood as a no. The use of Urim and Thummim (or "lo14 I however, also involves options with no sense of curse, such as in the selection of 'Siml $\|$ king (1 Sam 10:20-24). Furthermore, the withholding of Yhwh's word can be the resull $\sin$ in the community and not a no (1 Sam 14:37-46). In the last part of the chapter, K. Iow| at the connections with folktales, including a "male Cinderella" from Grimm, material Iı ı!ı Livy, and an "original" tale that had Saul getting a wife and a kingdom. It also discuss' understanding of Elohim as originally a "chthonic" god, based on the story in I Simun ' '

In the final, very brief chapter, K. argues for "original myths" reflecting "cullıuıl memory" that arc used and adapted in these stories; connections among these threc consmill as stories of an "ideal warrior" who experiences a downfall; and the end of "lie "'lunn'inl age of heroes." She argues that, although David is a hero, he is different and (luss rience either the separation from Yhwh or a downfall like his predecessors.

The volume would have benefited from further editing The comneclions |xidwinl chapters sometimes seem an afterthought. An example is the double discussion s) S' Sim birth in chaps. 2 and 3. Further, there are several small lapses, sucl ans lluc lark ol $\|$ d linl lin

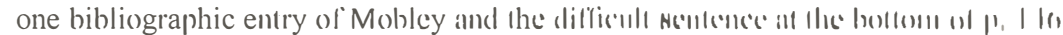

More substantively, there is a problem with the continued claim that these stories rely on earlier folktales. That might be possible, but the evidence is sparse or lacking, especially when parallels are often from non-Israelite and later materials. It is therefore nearly impossible to see how the stories were changed if earlier versions are not extant. Another issue is the treatment of Saul. K. assumes that Saul's story is relatively correct and that Saul was condemned by his own actions. Other scholars would argue that the negative portrayal of Saul is the result of the Deuteronomistic Historian's manipulation of accounts (such as Iransferring the birth story to Samuel) to justify David's ascension to the throne, and that Saul was actually a positive character unjustifiably condemned by later Judean editors who supported the "southern" David rather than the "northern" Saul. Finally, the claim that Saul ends the "heroic" period seems to ignore the military conquests of David and his physical attributes (cf. I Sam 16:12) and the expansion of the kingdom and building projects of Solomon.

This volume has three interesting aspects to its presentation: the continual connecting of biblical stories to folklore motifs; the argument that these three "hero" accounts are linked; and the idea that the Saul cycle ends the "heroic" period of ancient Israel. Each is worthy of consideration and further research.

John Spencer, Avenida Alozdra, San Diego, CA 92128 